\title{
Perancangan Buku Interaktif untuk Memperkenalkan Ragam Profesi Sebagai Sarana Pengembangan Minat Pelajar Usia Dini
}

\author{
Suri Mutia Siregar ${ }^{1}$, Budi Utomo², Lisa Marlina ${ }^{3}$ \\ ${ }^{1}$ Fakultas Psikologi, Universitas Sumatera Utara \\ ${ }^{2}$ Fakultas Kehutanan, Universitas Sumatera Utara \\ ${ }^{3}$ Fakultas Ekonomi dan Bisnis, Universitas Sumatera Utara
}

suri.mutia@usu.ac.id, budiutomo@usu.ac.id, lisamarlina143@yahoo.co.id

\begin{abstract}
Abstrak
Anak usia dini berada pada periode emas pertumbuhan (golden age) atau lima tahun pertama kehidupan. Proses tumbuh-kembang anak pada usia ini terjadi sangat pesat, dan akan menjadi penentu bagi kualitas anak di masa yang akan datang. Anak usia dini membutuhkan media pembelajaran yang dapat merangsang minat belajarnya sebagai bekal untuk mengikuti pendidikan sekolah dasar. Buku interaktif dapat menjadi salah satu media yang dipilih untuk pelajar usia dini. Ewers \& Bronwson, 1999; Haden, Reese, \& Fivush., 1996 (dalam Kozminsky dan Sadon, 2013) mengemukakan bahwa pelajar usia dini biasanya belajar lebih banyak ketika bahan bacaan yang diberikan mampu melibatkan mereka, dibandingkan jika mereka hanya menjadi pendengar pasif. Pengabdian ini bertujuan untuk merancang buku interaktif untuk memperkenalkan ragam profesi. Buku interaktif bertipe participation, yaitu buku yang berisi penjelasan atau cerita dengan disertai tanya jawab atau instruksi untuk menguji penjelasan yang ada di dalam buku. Sebagai tahap awal perancangan buku, Tim Pengabdian memperkenalkan 10 jenis profesi, yakni (1) nahkoda; (2) pengarang; (3) pemadam kebakaran; (4) kartografer; (5) teknisi robot; (6) koki; (7) masinis; (8) psikolog; (9) sutradara; dan (10) petani hidroponik. Saat ini, buku interaktif telah dicetak dan dikirimkan kepada anak-anak di Desa Pearung Silali, Kecamatan Paranginan, Kabupaten Humbang Hasundutan, Provinsi Sumatera Utara.
\end{abstract}

Kata Kunci: pelajar usia dini, buku interaktif, media pembelajaran, minat pelajar, ragam profesi

\section{PENDAHULUAN}

Desa Pearung Silali adalah salah satu Desa yang terletak di Kecamatan Paranginan, Kabupaten Humbang Hasundutan, Provinsi Sumatera Utara. Desa ini memiliki penduduk sebanyak 1244 jiwa, yang terdiri dari 616 laki - laki, dan 628 perempuan. Fasilitas pendidikan yang ada di Desa Pearung Silali adalah TK, SD, SMP, dan SMA.

Sarana Pendidikan Anak Usia Dini (PAUD) di Desa Pearung Silali adalah sebuah taman kanak kanak yang terletak di sebelah kantor kepala desa. Taman Kanak-Kanak di Desa ini memiliki halaman bermain yang terdiri dari hamparan rumput, namun belum dilengkapi dengan sarana permainan yang dapat memberikan rangsangan terhadap perkembangan fisik dan motorik.

Keterbatasan sumber daya yang dimiliki oleh Desa Pearung Silali menyebabkan taman kanakkanak di Desa belum sepenuhnya memiliki sarana dan prasarana yang memadai. untuk mengembangkan potensi anak usia dini. Padahal, sarana dan prasarana dapat menarik minat anak usia dini untuk mengeksplorasi lingkungan dan mengekspresikan keinginannya. Taman kanakkanak yang baik sedapat mungkin menghadirkan sarana dan prasarana yang memadai, dimana anak-

$$
\text { Pendidikan }
$$


anak dapat memenuhi kebutuhan perkembangannya serta memperkaya pengalaman yang dimiliki anak (Silmi dan Widayati, 2014).

Tidak hanya keterbatasan sarana dan prasarana, pandemi Covid-19 juga menghambat penyelenggaraan pendidikan di taman kanak-kanak Desa Pearung Silali. Penyebaran virus corona menyebabkan penundaan segala kegiatan di dalam dan di luar ruangan untuk semua sektor. Surat Edaran Nomor 4 Tahun 2020 tentang Pelaksanaan Kebijakan Pendidikan dalam Masa Darurat Penyebaran Coronavirus Disease (Covid-19) menyebutkan bahwa proses belajar dilakukan dari rumah melalui pembelajaran daring / jarak jauh untuk memberikan pengalaman belajar yang bermakna bagi siswa, tanpa terbebani tuntutan menuntaskan seluruh capaian kurikulum untuk kenaikan kelas maupun kelulusan (Menteri Pendidikan dan Kebudayaan Republik Indonesia, 2020).

Pembelajaran jarak jauh tidak hanya memberikan dampak terhadap guru, namun juga kepada siswa dan orang tua. Aji (2020) menyebutkan bahwa hadirnya wabah Covid - 19 yang sangat mendadak, menyebabkan dunia pendidikan Indonesia harus mengikuti alur yang dapat menolong kondisi sekolah dalam kondisi darurat. Sekolah perlu memaksakan diri untuk menggunakan media daring serta melaksanakan metode pembelajaran jarak jauh. Namun pelaksanaan metode pendidikan seperti ini juga menimbulkan beberapa masalah, seperti : (1) keterbatasan penguasaan teknologi informasi oleh guru dan siswa : dimana tidak seluruh guru di Indonesia paham mengenai penggunaan teknologi, terutama oada guru-guru yang lahir di tahun sebelum 1980 - an; (2) sarana dan prasarana yang kurang memadai : mahalnya perangkat pendukung teknologi menyebabkan sejumlah guru dan siswa tidak mampu untuk memiliki perangkat yang dibutuhkan demi mengikuti proses pembelajaran secara daring; (3) akses internet yang terbatas : dimana jaringan internet yang baik belum merata di seluruh pelosok negeri; dan (4) kurang siapnya penyediaan anggaran : ketidakmampuan guru dan siswa membayar kuota internet untuk memenuhi kebutuhan belajar daring menyebabkan proses pembelajaran jarak jauh menjadi terhambat. Kondisi ekonomi masyarakat yang belum sepenuhnya sejahtera serta kondisi jaringan internet desa yang kurang stabil menyebabkan masyarakat kesulitan untuk memberikan akses belajar daring kepada anak anak. Berdasarkan laporan dari Kepala Desa Pearung Silali, para guru terpaksa harus membuat giliran jadwal berkunjung ke rumah - rumah siswa untuk memberikan pembelajaran tatap muka di rumah. Guru - guru di Desa Pearung Silali biasanya berjalan kaki dari rumah ke rumah dengan membawa buku buku pelajaran di tengah kondisi cuaca yang kering dan berangin.

Dewi (2020) menyebutkan bahwa sekolahsekolah yang belum dapat menyelenggarakan kegiatan belajar-mengajar daring dapat mengembangkan kreativitas guru untuk memanfaatkan media belajar alternatif selama peserta didik belajar di rumah. Guru dapat menggunakan sumber belajar yang ada, seperti buku siswa sesuai dengan tema - tema yang diajarkan sesuai jadwal yang telah dibuat sebelumnya. Bagi pendidik anak usia dini, kegiatan pembelajaran di rumah akan menjadi sesuatu yang menarik sekaligus menantang. Peran pendidik anak usia dini yang selama ini tekun, ulet dan keratif dalam melakukan stimulasi perkembangan untuk perkembangan kognitif, bahasa, fisik motorik, sosial emosional, agama, moral, dan seni akan digantikan oleh orang tua peserta didik masing-masing (Hewi dan Asnawati, 2020).

Ketidaksiapan guru dalam menghadapi perubahan proses pembelajaran dapat mempengaruhi keberhasilan belajar anak. Hasil penelitian yang dilakukan oleh Ayuni, dkk (2020) menyebutkan bahwa masih terdapat beberapa guru taman kanak-kanak yang belum siap menghadapi perubahan pembelajaran pada masa pandemi Covid - 19. Ketidaksiapan ini terutama disebabkan oleh fasilitas yang kurang memadai, serta adanya persepsi dari orangtua yang menganggap bahwa perubahan proses pembelajaran merupakan hal yang sulit untuk diikuti.

Kurangnya rangsangan terhadap tumbuh kembang anak yang disebabkan oleh menurunnya mutu pendidikan tentu dapat mempengaruhi kualitas sumber daya manusia di kemudian hari. Hati dan Lestari (2016) menyebutkan bahwa untuk membentuk manusia yang berkualitas diperlukan berbagai upaya sejak dini, yaitu sejak anak masih berada pada masa balita. Siswina dkk (2016) menyatakan bahwa anak usia dini merupakan anak

$$
\text { Pendidikan }
$$


yang berada dalam proses pertumbuhan dan perkembangan yang unik, karena terjadi bersamaan dengan golden age (masa peka atau emas). Masa ini merupakan periode pertumbuhan dasar yang akan mempengaruhi dan menentukan perkembangan anak selanjutnya, sehingga setiap kelainan atau penyimpangan sekecil apapun akan mengurangi kualitas generasi penerus bangsa di kemudian hari.

Salah satu hal yang perlu dicermati guru dan orang tua dalam mengoptimalkan tumbuh kembang anak usia dini di masa pandemi Covid-19 adalah minat anak. Guru dan orang tua perlu membuat suatu metode pembelajaran yang dapat mengatasi rasa kebosanan anak, mengoptimalkan tujuan dari pembelajaran, serta meningkatkan minat anak (Munawir, 2018). Minat adalah kecenderungan yang tetap untuk memperhatikan dan mengenang beberapa kegiatan. Kegiatan yang diminati siswa, diperhatikan terus - menerus yang disertai rasa senang dan diperoleh rasa kepuasan (Slameto, 2003). Siagian dan Nurfitriyanti (2014) menyebutkan bahwa minat sangat besar pengaruhnya terhadap hasil belajar, karena apabila bahan pelajaran yang dipelajari tidak sesuai dengan minat, anak tidak akan belajar dengan baik sebab tidak menarik baginya. Anak akan malas belajar dan tidak akan mendapatkan kepuasan dari pelajaran tersebut. Ahmadi (2010) menyatakan, bahwa siswa akan mempunyai minat yang tinggi jika meningkat hasil pelajarannya, dan bahan pelajaran yang dianggap menarik bagi siswa akan lebih mudah dipelajari, sehingga hasil belajar siswa akan meningkat.

Komala (2017) menyebutkan ada beberapa cara untuk mengembangkan minat, potensi, maupun bakat pada anak usia dini, yaitu : (1) menciptakan lingkungan merangsang rasa ingin tahu anak dengan mengenalkannya pada berbagai hal atau kegiatan, misalnya dengan melakukan praktek sederhana, membuat kreasi, atau mengunjungi museum; (2) melibatkan anak dalam kegiatan curah ide (brainstorming) : meminta anak untuk melontarkan beragam ide dalam kelompok, dan kemudian membahas ide yang dilontarkan; (3) memberikan kesempatan untuk bereksplorasi dan mencoba memberikan peserta didik kebebasan untuk melakukan eksplorasi, menemukan hal baru, dan sesekali membuat kesalahan sehingga ia dapat belajar menelaah berbagai sudut pandang untuk memecahkan persoalan; (4) memunculkan motivasi internal dengan menghargai setiap ide maupun karya yang dihasilkan peserta didik secara proporsional serta menghindari memberi kritik yang dapat menimbulkan kekecewaan anak; dan (5) mengembangkan cara berpikir yang fleksibel, melatih anak untuk menelaah berbagai sudut pandang dalam menghadapi persoalan, serta memperkenalkan anak dengan orang - orang yang ahli dan kreatif.

Salah satu cara untuk mengembangkan minat anak adalah dengan memberikan kesempatan kepada anak untuk melakukan eksplorasi terhadap hal - hal baru. Pengenalan terhadap ragam profesi merupakan cara untuk memberikan stimulasi kepada anak mengenai pekerjaan yang dapat dilakukannya di masa yang akan datang serta menanamkan mimpi di benak anak-anak. Semakin banyak perbendaharaan anak terhadap ragam profesi, maka semakin luas pula kesempatan anak untuk melakukan eksplorasi terhadap potensi yang ia miliki, agar dapat dimanfaatkan di masa depan. Roe (1972) menyatakan bahwa pengalaman pada awal masa kanak-kanak memainkan peranan penting dalam pencapaian kepuasan dalam bidang yang dipilih seseorang. Super (1981) menyatakan periode sejak lahir hingga usia $14-15$ tahun, adalah masa perkembangan kapasitas, sikap, minat, dan kebutuhan yang terkait dengan konsep diri. Oleh karena, pengenalan ragam profesi sangat tepat dilakukan di usia dini untuk mengembangkan minat belajar anak.

Memperkenalkan ragam profesi pada anak usia dini dapat dilakukan dengan menggunakan media interaktif. Media interaktif adalah media dimana konsumennya dapat melakukan tindakan aktif dengan media yang disajikan. Tindakan aktif tersebut dapat dilakukan dengan cara meminta (penerima pesan) untuk melakukan kegiatan seperti menghitung, menulis, membaca, menirukan ucapan atau pelafalan, menjawab pertanyaan yang ditulis dalam buku catatan, mengamati lingkungan sekitar, membuat karangan singkat, dan lain sebagainya (Daryanto dalam Limanto, dkk., 2015). Briggs (dalam Adam dan Syastra, 2015) menyatakan bahwa media adalah segala alat fisik yang dapat menyajikan pesan serta merangsang peserta didik untuk belajar seperti buku, film, dan kaset.

Buku interaktif menurut The New Oxford Dictionary of English adalah buku yang digunakan

$$
\text { Pendidikan }
$$


sebagai sarana pembelajaran yang memiliki " $t w o$ way flow" pada informasi yang disampaikan kepada pembaca (dalam Limanto, dkk., 2015). Two way flop berarti ada interaksi dua arah antara buku sebagai sarana pembelajaran dan pembaca. Buku interaktif memiliki beberapa jenis, yaitu (1) buku interaktif dengan paper engineering (movable book) : buku yang menampilkan teknik lipatan dan potongan kertas pada halaman-halaman buku, sehingga memunculkan interaksi antara pembaca dengan buku. Beberapa yang termasuk jenis paper engineering adalah pop up (pada halaman terdapat lipatan kertas atau potongan yang dapat berdiri atau berbentuk tiga dimensi), pull tab (pada halaman terdapat kertas yang dapat ditarik), lift the flap (pada halaman terdapat bagian kertas yang dapat dibuka tutup untuk mengetahui kejutan di dalamnya), dan volvelles (pada halaman terdapat bagian yang dapat diputar); (2) buku interaktif peek a boo : buku interaktif yang mengharuskan pembaca untuk membuka terlebih dahulu untuk mengetahui kejutan di dalam buku tersebut; (3) buku interaktif participation: buku interaktif yang berisi penjelasan atau cerita dengan disertai tanya jawab atau instruksi untuk melakukan sesuatu guna menguji penjelasan atau cerita yang ada dalam buku tersebut; (4) buku interaktif hidden objects : buku mengajak pembaca untuk menemukan objek yang disamarkan dengan cara mengikuti alur cerita setiap halaman buku; (5) buku interaktif play a song atau play a sound: buku dilengkapi dengan tombol - tombol yang apabila ditekan akan mengeluarkan bunyi - bunyian berupa lagu ataupun suara yang berhubungan dengan cerita di dalam buku tersebut; (6) buku interaktif touch and feel : buku interaktif yang biasanya untuk anak prasekolah dengan tujuan untuk mengembangkan minat mereka dalam belajar mengenal tekstur, misalnya bulu halus pada gambar burung; dan (7) buku interaktif campuran : buku interaktif yang berisi gabungan dari beberapa buku interaktif.

Buku interaktif merupakan salah satu media belajar yang sesuai untuk anak usia dini. Fitriana (2015) menyebutkan bahwa buku interaktif dianggap cocok untuk anak, karena guru dapat menyampaikan materi dengan konsep bermain, menyenangkan, dan menarik minat anak. Buku juga merupakan media yang berbasis cetak dan visual, serta bersifat tahan lama hingga dapat digunakan berulang-ulang. Buku memberikan informasi sekaligus juga menghibur, sehingga sesuai untuk dijadikan salah satu pelengkap dalam mengajar anak-anak.

Pengenalan ragam profesi untuk mengembangkan minat pelajar usia dini dapat dilakukan dengan menggunakan buku interaktif jenis participation. Melalui buku jenis ini, orangtua dan guru dapat memberikan penjelasan atau cerita dengan disertai tanya jawab atau instruksi untuk melakukan sesuatu guna menguji penjelasan atau cerita yang ada dalam buku tersebut. Penggunaan buku interaktif jenis participation dalam memperkenalkan ragam profesi dapat memberikan kesempatan kepada guru dan orangtua untuk memberikan rangsangan kognitif kepada anak dengan cara yang menyenangkan. Anak juga dapat membina hubungan yang lebih akrab dengan orangtua maupun guru melalui cara belajar dua arah yang difasilitasi oleh buku interaktif jenis participation.

Berdasarkan uraian diatas, maka tim bermaksud untuk mengadakan pengabdian di Desa Pearung Silali yang bertujuan untuk mengembangkan minat pelajar anak usia dini melalui perancangan buku interaktif jenis participation. Buku interaktif rencananya akan memuat 4 muatan, yakni : (1) pengenalan 10 ragam profesi; (2) penjelasan mengenai profesi; (3) tanya jawab sederhana mengenai profesi; dan (4) instruksi untuk mewarnai gambar profesi.

\section{METODE}

Tim Pengabdian Universitas Sumatera Utara melakukan beberapa langkah untuk mengatasi permasalahan di Desa Pearung Silali, yaitu :

1. Pelaksanaan diskusi antara Tim Pengabdian Universitas Sumatera Utara dengan Perangkat Desa Pearung Silali mengenai permasalahan pendidikan anak usia dini;

2. Pelaksanaan kegiatan analisis permasalahan serta diskusi solusi yang dapat ditawarkan terkait permasalahan pendidikan anak usia dini di Desa Pearung Silali;

3. Perancangan produk yang dapat menyelesaikan permasalahan pendidikan anak usia dini di Desa Pearung Silali;

4. Penyerahan produk yang dapat menyelesaikan permasalahan pendidikan anak usia dini di Desa Pearung Silali; dan

5. Publikasi kegiatan di media massa

$$
\text { Pendidikan }
$$




\section{HASIL DAN PEMBAHASAN}

\section{Pelaksanaan diskusi antara Tim Pengabdian Universitas Sumatera Utara dengan Perangkat Desa Pearung Silali mengenai Permasalahan Pendidikan Anak Usia Dini}

Diskusi mengenai permasalahan pendidikan anak usia dini di Desa Pearung Silali dilakukan oleh Tim Pengabdian Universitas Sumatera Utara dan Perangkat Desa Pearung Silali melalui sambungan telepon seluler dan pesan media. Kondisi Pandemi Covid-19 selama kegiatan pengabdian menyebabkan Tim tidak dapat mengunjungi Desa untuk melakukan diskusi secara tatap muka. Berdasarkan hasil diskusi, ditemukan bahwa salah satu hal yang perlu dikembangkan pada anak usia dini di Desa Pearung Silali adalah minat belajar, yang sangat dibutuhkan sebagai bekal untuk menempuh pendidikan yang lebih tinggi.

2. Pelaksanaan Kegiatan Analisis Permasalahan serta Diskusi Solusi yang dapat Ditawarkan terkait Permasalahan Pendidikan Anak Usia Dini di Desa Pearung Silali;

Pelaksanaan kegiatan analisis serta diskusi solusi yang dapat ditawarkan terkait permasalahan pendidikan anak usia dini di Desa Pearung Silali dilakukan secara daring oleh Tim Pengabdian. Berdasarkan hasil diskusi, Tim bersepakat bahwa solusi yang ditawarkan untuk meningkatkan minat belajar anak usia dini adalah dengan membuat buku interaktif untuk memperkenalkan ragam profesi pada anak usia dini. Buku interaktif akan dirancang dengan tipe participation, yaitu buku yang berisi penjelasan atau cerita dengan disertai tanya jawab atau instruksi untuk melakukan sesuatu guna menguji penjelasan atau cerita yang ada dalam buku tersebut;

\section{Perancangan Produk yang dapat \\ Menyelesaikan Permasalahan Pendidikan Anak Usia Dini di Desa Pearung Silali; \\ Perancangan buku interaktif untuk} memperkenalkan ragam profesi dilakukan dengan melibatkan psikolog yang berasal dari Tim Pengabdian dan seorang ilustrator. Tim memutuskan untuk memasukkan 10 ragam profesi yang dianggap masih jarang dikenal oleh anak usia dini, sehingga dapat merangsang tumbuhnya minat anak karena mendapatkan paparan terhadap hal-hal baru, yaitu
(1) nahkoda;
(2) pengarang;
(3) pemadam

kebakaran; (4) kartografer; (5) teknisi robot; (6) koki; (7) masinis; (8) psikolog; (9) sutradara; dan (10) petani hidroponik. Berikut ini merupakan beberapa tampilan dari buku interaktif :

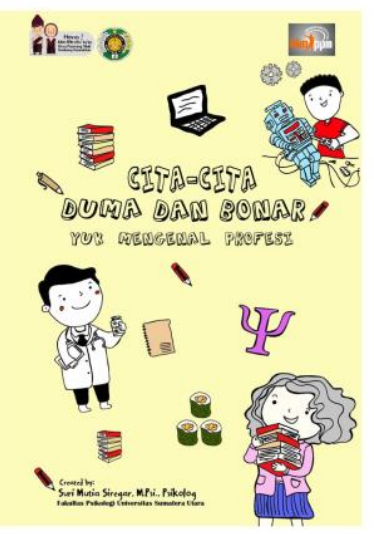

Gambar 1. (Tampilan Depan Buku Interaktif)

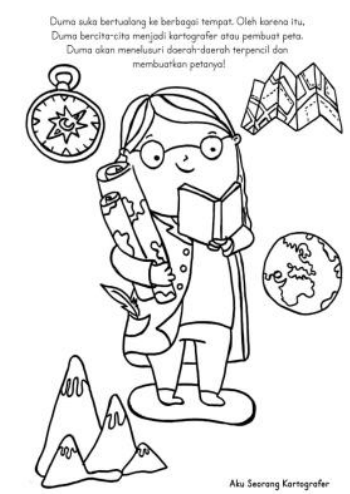

Gambar 2. (Tampilan Lembar Pengenalan Profesi Kartografer)

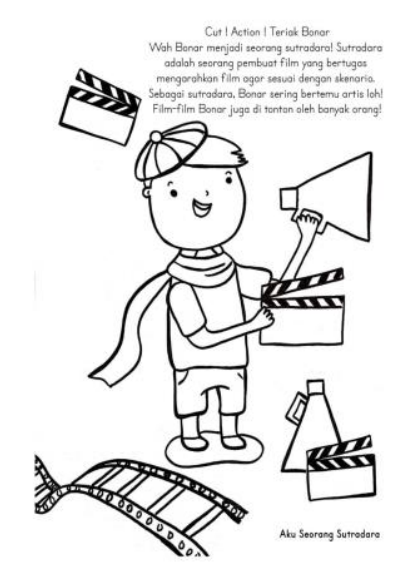

Gambar 3. (Tampilan Lembar Pengenalan Profesi Sutradara)

Pendidikan 
4. Penyerahan Produk yang Dapat Menyelesaikan Permasalahan Pendidikan Anak Usia Dini di Desa Pearung Silali

Penyerahan produk berupa buku interaktif dilakukan di Kantor Kepala Desa Pearung Silali. Perangkat Desa selanjutnya akan mendistribusikan buku kepada anak usia dini di Desa. Kondisi Pandemi Covid-19 menyebabkan Tim Pengabdian tidak dapat melakukan distribusi buku secara langsung kepada anak-anak.

\section{Publikasi Kegiatan di Media Massa}

Publikasi Kegiatan di Media Massa untuk memberikan informasi kepada masyarakat luas mengenai bentuk penyelesaian permasalahan pendidikan yang dilakukan di Desa Pearung Silali. Hal ini dilakukan sebagai salah satu upaya agar masyarakat juga memiliki alternatif solusi hal yang dapat dilakukan untuk meningkatkan minat belajar anak usia dini.

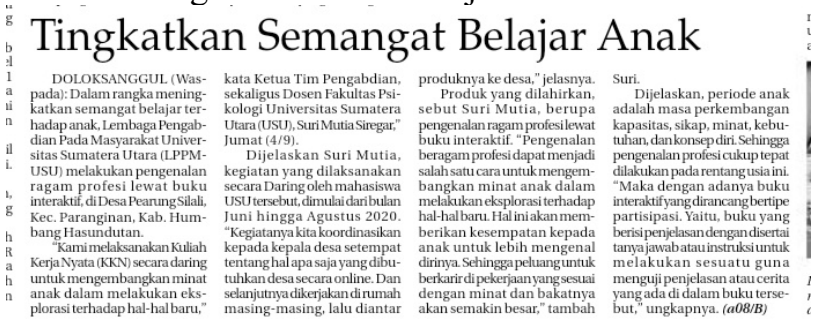

Gambar 4. (Publikasi Media Massa)

\section{Pengukuran Perubahan Aspek Kognitif Anak Setelah Menggunakan Buku Interaktif}

Pengukuran perubahan aspek kognitif anak dilakukan secara kualitatif terhadap 5 orang anak usia dini secara daring. Pada pengukuran awal, kelima orang anak belum memiliki wawasan mengenai beberapa profesi yang ditampilkan di buku seperti nahkoda, kartografer, masinis, psikolog, sutradara, dan petani hidroponik. Setelah mewarnai gambar dan mewarnai cerita, kelima anak dilaporkan dapat mengungkapkan kembali jenis-jenis profesi baru yang telah diperkenalkan secara naratif.

\section{KESIMPULAN}

Buku interaktif bertipe participation merupakan salah satu jenis media pembelajaran yang dapat digunakan untuk memperkenalkan ragam profesi kepada anak. Pengenalan ragam profesi tidak hanya dapat menanamkan cita-cita kepada anak, namun juga menarik minat belajar anak usia dini. Pengembangan yang masih perlu dilakukan dalam pengabdian ini adalah pengukuran kondisi minat belajar anak sebelum dan sesudah mendapatkan buku interaktif secara kuantitatif. Saat pengabdian berlangsung, pengukuran terhadap anak hanya dapat dilakukan secara kualitatif pada beberapa anak karena terbatasnya akses terhadap anak di Desa akibat pandemi covid-19.

\section{UCAPAN TERIMAKASIH}

Tim Pengabdian mengucapkan terimakasih kepada Lembaga Pengabdian/Pelayanan Kepada Masyarakat Universitas Sumatera Utara, Pengelola kegiatan Kuliah Kerja Nyata (KKN) PPM USU, Mahasiswa KKN PPM USU yang tergabung dalam kelompok KHH_R86, serta segenap Perangkat Desa dan Masyarakat Desa Pearung Silali, Kabupaten Humbang Hasundutan, Sumatera Utara yang telah banyak memberikan dukungan dan sumbang saran terhadap pelaksanaan kegiatan ini.

\section{REFERENSI}

Ada, dan Syastra. (2015). Pemanfaatan Media Pembelajaran Berbasis Teknologi Informasi bagi Siswa Kelas X SMA Ananda Batam. CBIS Journal, Volume 3 No. 2, ISSN : 2337 - 8794

Ahmadi, Farid. (2010). Meningkatkan Minat Membaca Siswa Sekolah Dasar dengan Metode Glenn Doman Berbasis Multimedia. Jurnal Penelitian Pendidikan. 27 (1) Halaman 68 - 75

Aji, R.H.S. (2020). Dampak Covid-19 pada Pendidikan di Indonesia : Sekolah, Keterampilan, dan Proses Pembelajaran. Salam : Jurnal Sosial dan Budaya Syar'I FSH UIN Syarif Hidayatullah Jakarta Volume 7 No. 5 (2020), Halaman 295 - 402, DOI : 10.15408/sjsbs.v7i5.15314

Ayuni, dkk. (2020). Kesiapan Guru TK Menghadapi Pembelajaran Daring Masa Pandemi Covid - 19. Jurnal Obsesi : Jurnal Pendidikan Anak Usia Dini, Volume 5 Issue 1 (2021) Halaman 414 421, ISSN : 2549-8959 (Online) 2356 - 1327 (Print)

Dewi, W.A.F. (2020). Dampak Covid - 19 terhadap Implementasi Pembelajaran Daring di Sekolah Dasar. Jurnal Ilmu Pendidikan. Volume 2 Nomor 1 April 2020 Halaman 55 - 61, e-ISSN 2656-

$$
\text { Pendidikan }
$$


8071

Fitriana, Rina. (2015). Perancangan Buku Interaktif sebagai Penunjang Aktivitas Belajar Pos PAUD Usia 3-4 Tahun di Kelurahan Tugu-Depok. E-Proceeding of Art \& Design, Vol. 2, No. 2. ISSN : 2355 - 9349

Hati dan Lestari. (2016). Pengaruh Pemberian Stimulasi pada Perkembangan Anak Usia 12 - 36 Bulan di Kecamatan Sedayu, Bantul. Jurnal Ners dan Kebidanan Indonesia, Halaman 44 - 48, ISSN : 2354-7642

Hewi dan Asnawati. (2020). Strategi Pendidik Anak Usia Dini Era Covid - 19 dalam Menumbuhkan Kemampuan Berpikir Logis. Jurnal Obsesi : Jurnal Pendidikan Anak Usia Dini, Volume 5 Issue 1 (2021) Halaman 158 - 167, ISSN : 25498959 (Online) 2356 - 1327 (Print)

Komala. (2017). Stimulasi Melejitkan Potensi, Minat, dan Bakat pada Anak Usia Dini. Jurnal Tunas Siliwangi Vol. 3 No. 2 Halaman 181 194

Kozminsky dan Sadon. (2013). Media Type Influences Preschooler's Literacy Development : EBook versus Printed Book Reading. IJELLO Special Series of Chais Conference 2013 Best Papers Volume 9, 2013

Limanto, dkk. (2015). Perancangan Buku Pembelajaran Interaktif Sejarah Peringatan Hari Hari Perjuangan Nasional untuk Anak Usia 6-11 Tahu. Jurnal DKV Adiwarna, Universitas Kristen Petra, Vol. 1, No. 6, diakses dari : https://media.neliti.com/media/publications/84487ID-none.pdf

Menteri Pendidikan dan Kebudayaan Republik Indonesia. (2020). Surat Edaran Nomor 4 Tahun 2020 tentang Pelaksanaan Kebijakan Pendidikan dalam Masa Darurat Penyebaran Coronavirus Disease (COVID - 19). Diakses dari : https://jdih.kemdikbud.go.id/arsip/SE\%20Menteri\%
20Nomor\%204\%20Tahun\%202020\%20cap.pdf

Munawir, A.S. (2018). Meningkatkan Minat Belajar Anak Melalui Pembelajaran di Luar Kelas pada Anak Kelompok A Tk Joyful Kids Palu. Early Childhood Education Indonesian Journal, Volume 1 No. 2 Hal. 38-44, ISSN : 2613 - 8972

Presiden Republik Indonesia. (2012). Undang - Undang Republik Indonesia Nomor 12 Tahun 2012 tentang Pendidikan Tinggi. Diakses dari : http://www.polsri.ac.id/panduan/01.\%20umum/06. $\%$ 20Undang-

Undang\%20Republik\%20Indonesia\%20Nomor\%20 $12 \% 20$ Tahun $\% 202012 \% 20$ Tanggal $10 \% 20$ Agustus \%202012\%20Tentang\%20Pendidikan\%20Tinggi.P DF

Presiden Republik Indonesia. (2003). Undang - Undang Republik Indonesia Nomor 20 Tahun 2003 Tentang Sistem Pendidikan Nasional. Diakses dari : http://luk.staff.ugm.ac.id/atur/UU202003Sisdiknas.pdf

Roe, A. (1972). Prospectus in Whiteley, J.M. and Renikoff (ed). Perspective on Vocational Develompment. Washington D.C. : American Personell Guidance Association

Silmi dan Widayati. (2014). Survei Sarana dan Prasarana Outdoor di Taman Kanak-kanak Kecamatan Bubutan Surabaya. Jurnal PAUD Teratai Online Program Studi S-1 Pendidikan Guru Pendidikan Anak Usia Dini - Fakultas Ilmu Pendidikan UNESA Volume 03 No 03 Halaman 1 7

Super, S.E. (1991). Approach to Occupational Choice and Career. England : Hobson Press

Slameto. (2003). Belajar dan Faktor - Faktor yang Mempengaruhinya. Jakarta : PT. Raja Grafindo Persada 